(2)

CORPUS PUBLISHERS

\section{Journal of Mineral} and Material

\section{Science (JMMS)}

\section{Volume 3 Issue 1, 2022}

Article Information

Received date : January 28, 2022

Published date: February 01, 2022

\section{${ }^{*}$ Corresponding author}

Ya V Kryukov, Candidate of science in Economics, Senior Researcher of the Center for Resource Economics, IEIE RAS, Russia

Distributed under Creative Commons CC-BY 4.0

\title{
The Coal Industry in Australia and the East of Russia: A Lot in Common, But There Are Differences
}

\section{Ya V Kryukov*}

Candidate of science in Economics, Senior Researcher of the Center for Resource Economics, IEIE RAS, Russia

Opinion

The mineral resource sector of Russia and Australia, despite all the historically determined differences, has some common features. This similarity is largely determined by the role that the coal industry has played and continues to play in the economies of each country. Countries have comparable shares of the world's total proven coal reserves, with Australia significantly ahead of Russia in terms of production (Figures 1 \& 2). Coal was one of the first Australian exports, and deposits of this mineral near Newcastle have been exploited since 1800. Australia has the second largest proven reserves in the world after the United States. The country's coals are represented by a full range of species and are of high quality. The main coal mining areas are located in the eastern part of the mainland - in the states of New South Wales and Queensland, where premium quality coals are developed. Australia, which has $10 \%$ of the world's coal reserves and is the world's largest exporter of coking coal. Open pits account for $80 \%$ of production. Australia generates more than $60 \%$ of its electricity from coal and exported more than $\$ 50$ billion worth of this raw material in 2021 - more than $10 \%$ of the country's total exports. In Russia, almost $80 \%$ of the predicted coal resources are also located in the eastern part of the country - in Siberia (Kuzbass Region, Krasnoyarsk Region, the Republic of Khakassia, Irkutsk Region and Primorsky Region). The European part of the country contains less than $9 \%$ of explored reserves, the Far East - about 10\%. Two-thirds of the coal mined is produced by open-pit mining: 11 open pits produce hard coal and seven lignite. Underground mining is carried out at eight mines located in Siberia and the Far East [1]. Comparison of the volumes of coal production in Russia and in Australia illustrates the discrepancy between the volumes of Russian production and its resource base. This is primarily due to the geographical location of the coal industrial centers, located far from both Pacific ports and European consumers. More than half of Russian reserves are represented by brown coal. The rest is coal and anthracites; the share of the latter in the structure of reserves does not exceed 3\%. Both the Australian and Russian coal mining industries are oriented to the Asia-Pacific markets (primarily to China, where the competition between suppliers from Russia and Australia has become particularly evident in the last two years). Despite the fact that China produces almost half of the world's coal, the country needs a high-quality coking coal for steel industry. This high-quality material is primarily mined in Australia. China imports about $5 \%$ of its total thermal coal consumption.

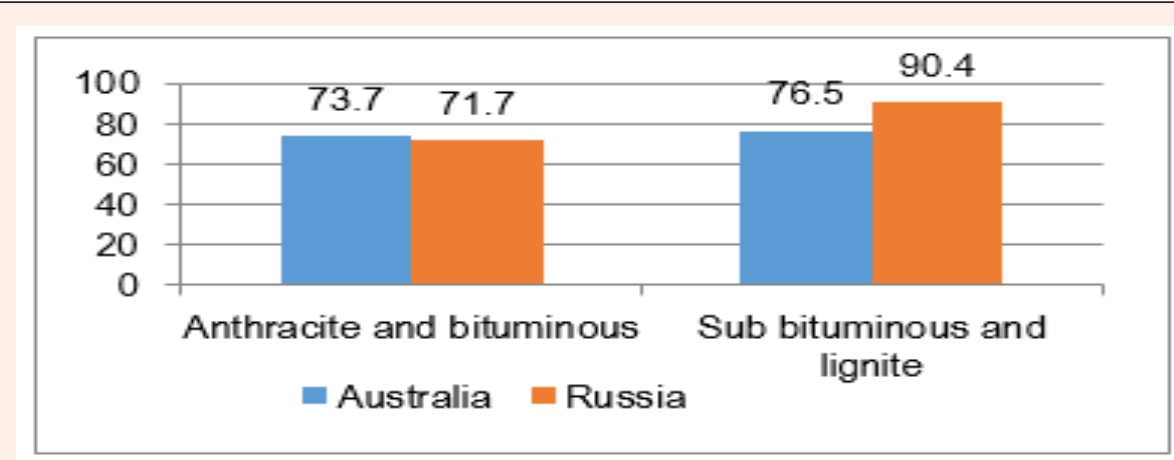

Figure 1: Proved coal reserves at end 2020 (BP Statistical Review of World Energy 2021.) (bn t).

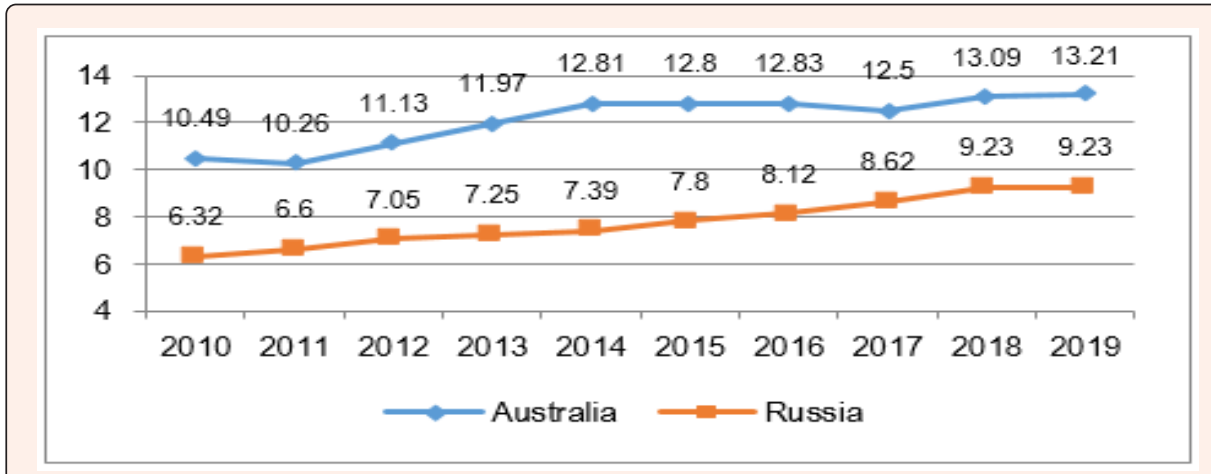

Figure 2: Coal production (exajoules). 
In 2021, China faced a shortage of coal due to a decrease in production by Chinese coal companies caused by restrictive measures under the green agenda and safety checks at coal mines. In addition, in 2020-2021 in this country there was an informa ban on the import of Australian coal. The ban comes after several political speeches by the Australian government against Beijing over the origins of COVID-19 and human rights in China. It is not easy to increase imports from other key suppliers (Russia and Mongolia) due to the limited capacity of the railways. In the long term, Russia could benefit from the energy crisis in China. As an energy exporter, Moscow wil increase gas supplies to China, and will also be able to the expansion of joint energy projects. The growing demand for coal from India makes it possible to look positively at the future of the Australian coal industry on the horizon until 2050, as India has not yet committed to achieving zero energy consumption plan. In addition, China has set itself a longer target of reaching zero energy consumption - 2060. Australia intends to achieve carbon neutrality by 2050 . However, some representatives of the federal government believe that a well-developed Australian coal industry can also exist in a carbon-neutral environment. At the same time, there are proposals to create a government-funded credit scheme to ensure further investment in the coal sector. Achieving carbon neutrality is supposed to be achieved through carbon capture and storage, not through shutting down the coal mining industry.

The main goal of the government is to ensure the protection of the country's coal and gas sectors, heavy industry and agriculture, but at the same time promote the use of hydrogen, introduce carbon capture and storage systems, and ensure soil carbon absorption. In this way, Australia will achieve emission reduction targets through technology investment and innovation, not through high taxes. In Russia, little attention is paid to these issues of development of the fuel and energy sector and the East of the country. The main emphasis is on creating of an infrastructure for entering the markets of Southeast Asia and the Asia-Pacific region. A direct consequence of this approach is the orientation of companies on the supply of energy resources for export, while other issues (socio-economic development) have a low priority. In 2021 the Russian Government prepared a draft resolution obliging some Siberian coa companies wishing to increase supplies to Asia to give part of their export earnings to the region's economy [2]. One of the options for using income is the implementation of projects aimed at restructuring the economy. The reason of a depressed state of the economy of Kuzbass Rand (as well as the coal basins of the Krasnoyarsk Region, the Republic of Khakassia, Irkutsk Region and Primorsky Region) is an increase in the efficiency of the coal industry and the resulting significant release of employed workers. At the same time, the synchronization of the development of the coal industry with the creation of new jobs and new areas of employment was not considered. On the one hand, new projects for the development of coal deposits of better quality with greater export potential are being implemented, which are poorly synchronized with the adaptation of the "old" coal mining areas to solve the emerging acute social problems of employment and elimination of the earlier environmental damage. On the other hand, transport infrastructure, the availability of which can serve as the basis for the development of new energy projects (including renewable energy sources), and improve living standards [3].

Relatively low prices on the domestic market, combined with the need to make significant investments in the development of new sources of energy resources, as well as the need to purchase many critical types of technological equipment, the government seeks to compensate with tax incentives and preferences. Domestic production of equipment does not meet the demand for its supply. At the same time, it should be noted that there are a number of scientific and industrial centers in the East of the country - cities of Omsk, Novosibirsk, Krasnoyarsk, Irkutsk, Khabarovsk, Vladivostok. A targeted system of measures and steps to use and develop the potential still available in these centers for the development of relevant production for the needs of the fuel and energy and mining industries is still waiting to be taken [4] The fundamental problem with increasing the export of Russian coal in the eastern direction is to ensure the relationship of export vector with the solution of socioeconomic and environmental regional problems. The green agenda in these conditions does not have the same priority as in Australia.

\section{Funding}

This paper is based on the results of the research conducted with the financial support of the Russian Federation represented by the Ministry of Science and Higher Education of Russia in the framework of a major research project "Socio-economic development of Asian Russia based on the synergy of transport accessibility, system knowledge of natural resource potential, expanding space of interregional interactions”, Agreement № 075-152020-804 from 02.10.2020. (grant № 13.1902.21.0016).

\section{References}

1. Ministry of Natural Resources and Environment of the Russian Federation. State Report, The condition and using of mineral resources in Russia in 2020.

2. Milkin V, Potapova K (2021) The authorities will oblige coal miners of Kuzbass to give part of their income to the region.

3. Potayeva K (2021) The Baikal-Amur Mainline is stuck with coal. BAM modernization projects won't allow to relieve Transsib significantly.

4. (2021) Russia will build an analogue of the BAM to export coal from the record field. 